Prismatika: Jurnal Pendidikan dan Riset Matematika Vol. 3 No. 1 (2020)

p-ISSN: 2654-6140, e-ISSN: 2656-4181

http://ejurnal.budiutomomalang.ac.id/index.php/prismatika

\title{
MENGUKUR HASIL BELAJAR SISWA MELALUI MODEL PEMBELAJARAN STAD (STUDENT TEAMS ACHIEVEMENT DIVISION)
}

\author{
Ivanatul Nurizza ${ }^{1}$, Wuli Oktiningrum ${ }^{2}$ \\ Universitas Islam Raden Rahmat Malang ${ }^{1,2}$ \\ ivannurizza@gmail.com ${ }^{1}$, wulie.okti@gmail.com²
}

\begin{abstract}
Abstrak
Pelaksanaan proses belajar mengajar pada umumnya masih menggunakan model pembelajaran konvensional sehingga berakibat pada rendahnya hasil belajar matematika siswa. Penelitian ini bertujuan untuk mengukur hasil belajar siswa melalui model pembelajaran STAD (Student Teams Achievement Division) dan pembelajaran konvensional. Penelitian ini menggunakan rancangan penelitian kuantitatif quasi eksperiment dengan melihat perbedaan hasil nilai matematika pada pre-test dan post-test antara kelas kontrol dan kelas eksperimen. Berdasarkan analisis data didapatkan hasil penelitian yang menunjukkan bahwa ada perbedaan hasil belajar matematika siswa kelas IV yang menggunakan model pembelajaran Student Teams Achievement Division (STAD) dan pembelajaran konvensional. Hal ini dibuktikan berdasarkan nilai rata-rata kelas kontrol yang mengalami kenaikan sebesar 9,88\% dari 54,36 menjadi 64,24 sedangkan nilai rata-rata kelas pada kelas eksperimen mencapai $24,92 \%$ dari 55,80 menjadi 80,72 .
\end{abstract}

Kata kunci: hasil belajar, model pembelajaran konvensional, STAD

\begin{abstract}
Implementation of the teaching and learning process in general still use conventional learning models so as to result in low mathematics learning outcomes of students, especially in the surrounding material and flat building area. This study aimed to measure the differences in learning outcomes of class IV students through STAD (Student Teams Achievement Division) learning model and conventional learning. This study used quasi-experimental quantitative research design by looking at the differences in mathematical value results in pre-test and post-test between control class and experimental class. Based on the data analysis, the results of the study showed that there were differences in the learning outcomes of mathematics students of class IV who use the learning model Student Teams Achievement Division (STAD) and conventional learning. This was evidenced by the average value of the control class which increased by $9.88 \%$ from 54.36 to 64.24 while the average value of the class in the experimental class reached $24.92 \%$ from 55.80 to 80.72 .
\end{abstract}

Keywords: learning outcomes, conventional learning models, STAD 


\section{PENDAHULUAN}

Pendidikan matematika mempunyai peran penting untuk mempersiapkan kualitas SDM. Geometri sebagai salah satu ruang lingkup matematika merupakan pengetahuan dasar yang harus dipelajari oleh peserta didik sebagai sarana untuk menumbuh kembangkan kemampuan berpikir dan kemampuan dalam bekerja sama (Depdiknas, 2007). Selaras dengan Zalima, dkk (2020) yang berpendapat bahwa pembelajaran matematika memiliki peranan penting dalam peningkatan kemampuan berpikir peserta didik.

Pembelajaran matematika merupakan kegiatan yang dilakukan agar kegiatan pembelajaran lebih bermakna (Fuadi, Johar, \& Munzir, 2016). Sedangkan pembelajaran matematika di Indonesia pada umumnya lebih dititik beratkan pada keterampilan berhitung (NCTM, 2000). Hal ini dibuktikan berdasarkan publikasi perbandingan prestasi belajar matematika siswa oleh TIMSS dimana siswa Indonesia menduduki posisi pada tingkat rendah dengan skor rata-rata 400 (Hadi, 2019). Hal ini dikarenakan penerapan kurikulum 2013 tidak terealisasikan dengan baik dimana dalam pelaksanaan pembelajaran pada umumnya masih menerapkan pembelajaran konvensional. Pembelajaran konvensional lebih mengutamakan hafalan dan keterampilan berhitung, serta mengutamakan hasil dari pada proses sehingga pada prosesnya secara keseluruhan masih berpusat pada guru (Ruseffendi, 2005).

Model STAD (Student Teams Achievement Division) dapat dijadikan pilihan untuk meningkatkan hasil belajar siswa. Berdasarkan penelitian terdahulu, penggunaan model STAD dapat meningkatkan hasil belajar siswa. Hasil belajar siswa adalah hasil dari interaksi belajar dan mengajar (Dimyati \& Mudjiono, 2006). Hasil belajar yang dimaksud adalah kemampuan kognitif yang meliputi kemampuan menyatakan kembali fakta, prinsip dan konsep matematika yang telah dipelajari.

Analisis mendalam diperlukan untuk mendeskripsikan perbedaan hasil belajar menggunakan model pembelajaran STAD dengan konvensional. Oleh sebab itu, berdasarkan uraian di atas peneliti akan mendeskripsikan perbedaan hasil belajar matematika siswa kelas IV SDN Mergosono 1 Malang yang menggunakan model pembelajaran STAD dengan model pembelajaran konvensional .

\section{METODE PENELITIAN}

Pendekatan penelitian ini adalah kuantitatif deskriptif. Sedangkan jenis penelitiannya adalah eksperimen semu (quasi eksperiment) dengan non equivalent control group design. Tujuan penelitian deskriptif adalah memberi 
gambaran mengenai suatu fenomena sosial (Mulyadi, 2011). Penelitian dilakukan di SDN Mergosono 1 Kota Malang, dengan kelas kontrol dan kelas eksperimen berturut-turut adalah kelas IV-A dan IV-B. Materi difokuskan pada keliling dan luas persegi dan persegi panjang.

Instrumen penelitian terdiri dari (1) kisi-kisi soal, (2) rencana pelaksanaan pembelaaran (RPP), dan (3) lembar kerja siswa (LKS). Instrumen pengambilan data yang digunakan adalah soal tes esai sebanyak 5 butir. Sebagai langkah validasi instrumen, peneliti melakukan konsultasi dan revisi kepada pembimbing untuk menyempurnakan format dan isi instrumen. Selain itu, untuk menguji kualitas soal tersebut, dilakukan serangkaian uji coba instrumen diantaranya (1) uji validitas, (2) uji reliabilitas, (3) uji taraf kesukaran, dan (4) uji daya pembeda. Teknik analisis data menerapkan analisis perbedaan dengan rumus Independent Sample TTest. Uji normalitas dan homogenitas dilakukan terlebih dahulu sebagai prasyaratnya (Riadi, 2016).

\section{HASIL DAN PEMBAHASAN}

Berdasarkan hasil tes pada materi keliling dan luas bangun datar diperoleh data pada tabel 1 sebagai berikut.

Tabel 1. Desctriptive Statistics

\begin{tabular}{|c|c|c|c|c|c|}
\hline & $\mathrm{N}$ & Minimum & Maximum & Mean & $\begin{array}{c}\text { Std. } \\
\text { Deviation }\end{array}$ \\
\hline Pre-Test dari Kelas Kontrol & 25 & 42 & 71 & 54,36 & 6,885 \\
\hline $\begin{array}{l}\text { Post-Test dari Kelas } \\
\text { Kontrol }\end{array}$ & 25 & 48 & 82 & 64,24 & 9,816 \\
\hline $\begin{array}{l}\text { Pre-Test dari Kelas } \\
\text { Eksperimen }\end{array}$ & 25 & 47 & 67 & 55,80 & 4,491 \\
\hline $\begin{array}{l}\text { Post-test dari Kelas } \\
\text { Eksperimen }\end{array}$ & 25 & 52 & 98 & 80,72 & 12,568 \\
\hline Valid N (listwise) & 25 & & & & \\
\hline
\end{tabular}

Tabel 1 menunjukkan bahwa nilai rata-rata tes sebelum pembelajaran tidak jauh berbeda yakni 54,36 pada kelas kontrol dan 55,80 pada kelas eksperimen. Hal ini mengindikasikan bahwa kemampuan awal siswa antara kelas kontrol dan kelas eksperimen hampir sama. Setelah dilaksanakan proses pembelajaran didapatkan perbedaan pada nilai rata-rata tes yaitu 64,24 pada kelas kontrol dan 80,72 pada kelas eksperimen. Untuk memberikan gambaran yang lebih jelas, maka data deskriptif statistik dibuat dalam diagram sebagai berikut. 


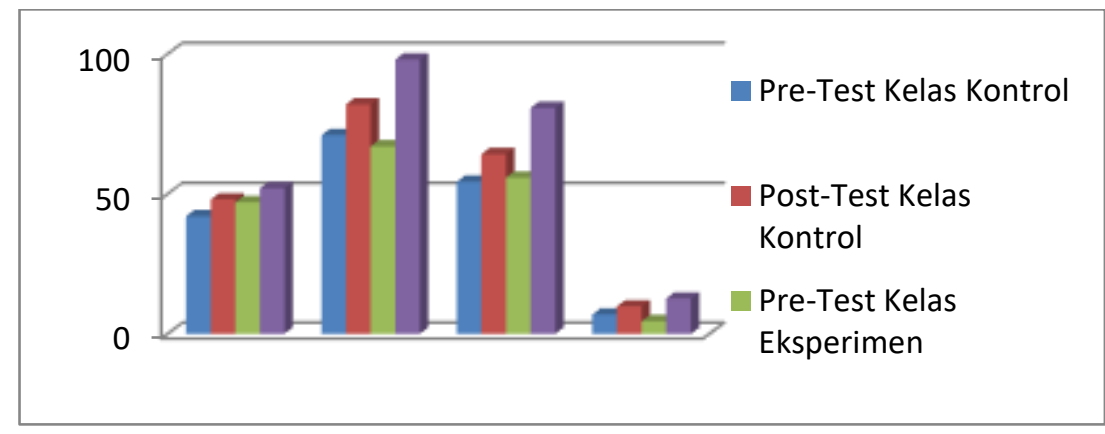

Gambar 1. Diagram Deskriptif Statistik

Tabel 2. Test of Normality

\begin{tabular}{cccccccc}
\hline \multirow{2}{*}{ Kelas } & \multicolumn{2}{c}{ Kolmogorov-Smirnov } & \multicolumn{3}{c}{ Shapiro-Wilk } \\
\cline { 2 - 8 } & Statistic & df & Sig. & Statistic & df & Sig. \\
\hline $\begin{array}{c}\text { Helajar } \\
\text { Siswa }\end{array}$ & $\begin{array}{c}\text { Pre-Test } \\
\text { Kelas IV-A }\end{array}$ & 0,114 & 25 & 0,200 & 0,979 & 25 & 0,874 \\
\cline { 2 - 8 } & $\begin{array}{c}\text { Post-Test } \\
\text { Kelas IV-A }\end{array}$ & 0,131 & 25 & 0,200 & 0,964 & 25 & 0,507 \\
\cline { 2 - 8 } & $\begin{array}{c}\text { Pre-Test } \\
\text { Kelas IV-B }\end{array}$ & 0,125 & 25 & 0,200 & 0,971 & 25 & 0,678 \\
\cline { 2 - 8 } & $\begin{array}{c}\text { Post-Test } \\
\text { Kelas IV-B }\end{array}$ & 0,135 & 25 & 0,200 & 0,946 & 25 & 0,204 \\
\hline
\end{tabular}

Berdasarkan tabel 2 dapat diketahui pada kolom Kolmogorov-Smirnov muncul nilai signifikansi sebesar 0,200 untuk kedua variabel tersebut lebih besar dari 0,05. Jadi data nilai tes pada kedua kelas berdistribusi secara normal. Setelah diketahui bahwa data telah terdistribusi secara normal, selanjutnya dilakukan uji paired sample t-test yang bertujuan untuk mengetahui perbedaan rata-rata tes pada kedua kelas secara berpasangan. yang ditunjukkan dalam Tabel 3.

Tabel 3. Paired Sample Test

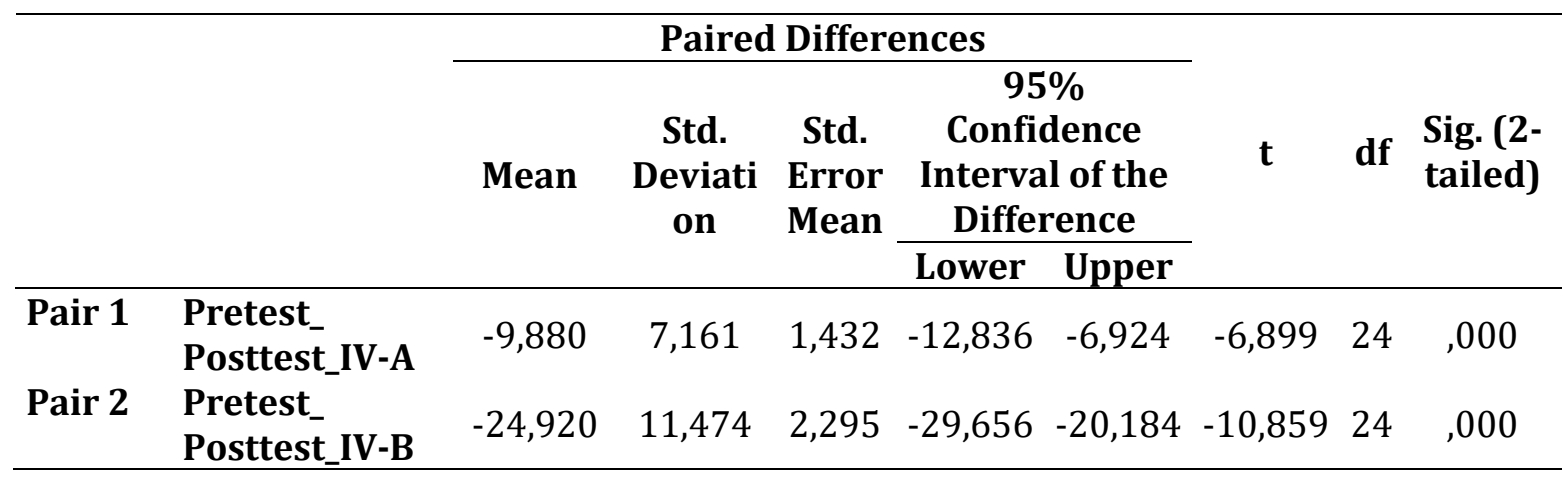


Berdasarkan tabel 3, nilai sig. (2-tailed) 0,000 $<0,05$ sehingga dapat dikatakan bahwa terdapat perbedaan rata-rata pre-test dan post-test kelas kontrol. Nilai sig. (2-tailed) pada pre-test kelas eksperimen dengan post-test kelas eksperimen 0,000 $<0,05$ sehingga dapat dikatakan bahwa terdapat perbedaan rata-rata antara pre-test dan post-test kelas eksperimen. Selanjutnya dilakukan uji homogenitas untuk mengetahui apakah kelas IV-A dan kelas IV-Bmempunyai kemampuan yang sama atau tidak yang disajikan dalam tabel 4 sebagai berikut.

Tabel 4. Levene Statistic

\begin{tabular}{cccc}
\hline \multicolumn{4}{c}{ Hasil Belajar Siswa } \\
\hline Levene Statistic & df1 & df2 & Sig. \\
\hline 2,281 & 1 & 48 & 0,138 \\
\hline
\end{tabular}

Tabel 4 menunjukkan nilai signifikansi yang dihasilkan sebesar 0,138 lebih besar dari 0,05, sehingga disimpulkan bahwa data memiliki varians yang sama atau homogen yang berarti bahwa kelas IV-A dan kelas IV-B mempunyai kemampuan yang sama. Setelah diketahui data telah terdistribusi secara normal dan homogen, selanjutnya dilakukan uji independent sample test untuk menguji hipotesis. Hasil uji tersebut disajikan dalam Tabel 5 sebagai berikut.

Tabel 5. Independent Sample Test

\begin{tabular}{llccc}
\hline & & \multicolumn{3}{c}{ t-test for Equality of Means } \\
\cline { 3 - 5 } & $\begin{array}{c}\text { Sig. (2- } \\
\text { tailed) }\end{array}$ & $\begin{array}{c}\text { Mean } \\
\text { Difference }\end{array}$ & $\begin{array}{c}\text { Std. Error } \\
\text { Difference }\end{array}$ \\
\hline $\begin{array}{l}\text { Hasil } \\
\text { Belajar }\end{array}$ & $\begin{array}{l}\text { Equal variances } \\
\text { assumed }\end{array}$ & 0,000 & $-16,480$ & 3,189 \\
& $\begin{array}{l}\text { Equal variances not } \\
\text { assumed }\end{array}$ & 0,000 & $-16,480$ & 3,189 \\
\hline
\end{tabular}

Berdasarkan analisis data di atas, hasil uji hipotesis nilai posttestkedua kelas diperoleh nilai sig. (2-tailed) 0,000<0,05. Hal ini menunjukkan bahwa terdapat perbedaan hasil belajar siswa (Y) yang menggunakan model pembelajaran STAD (X1) dan model pembelajaran konvensional (X2). Hasil hipotesis di atas sesuai dengan pendapat (Suprijono, 2009) bahwa model pembelajaran kooperatif dikembangkan untuk meningkatkan hasil belajar siswa. Selanjutnya dilakukan analisis lebih lanjut dari kemampuan siswa dalam memahami setiap butir soal yang ditunjukkan melalui persentase skor jawaban benar siswa sebagaimana tersaji dalam Tabel 6. 
Tabel 6. Perbandingan Persentase Skor Tiap Butir Soal

\begin{tabular}{|c|c|c|c|c|c|}
\hline \multirow{3}{*}{ No } & \multirow{3}{*}{ Indikator Soal } & \multicolumn{4}{|c|}{ Hasil Post-Test Siswa } \\
\hline & & \multicolumn{2}{|c|}{ Kelas Kontrol } & \multicolumn{2}{|c|}{ Kelas Eksperimen } \\
\hline & & $\begin{array}{l}\text { Skor } \\
\text { Total }\end{array}$ & $\begin{array}{c}\text { Persentase } \\
\text { Skor (\%) }\end{array}$ & $\begin{array}{l}\text { Skor } \\
\text { Total }\end{array}$ & $\begin{array}{c}\text { Persentase } \\
\text { Skor (\%) }\end{array}$ \\
\hline 1 & $\begin{array}{l}\text { Disediakan gambar ilustrasi } \\
\text { bingkai foto, siswa dapat } \\
\text { menentukan keliling foto } \\
\text { dengan benar } \\
\text { (Soal No.5) }\end{array}$ & 230 & $46 \%$ & 411 & $82,2 \%$ \\
\hline 2 & $\begin{array}{l}\text { Disediakan gambar persegi } \\
\text { dengan ukuran tertentu dan } \\
\text { gambar persegi satuan, siswa } \\
\text { dapat menghitung jumlah } \\
\text { persegi satuan dengan benar } \\
\text { (Soal No.3) }\end{array}$ & 390 & $78 \%$ & 418 & $83,6 \%$ \\
\hline 3 & $\begin{array}{l}\text { Disediakan ilustrasi tentang } \\
\text { pekarangan berbentuk } \\
\text { persegi panjang, siswa dapat } \\
\text { menentukan keliling persegi } \\
\text { panjang menggunakan rumus } \\
\text { keliling persegi panjang } \\
\text { dengan benar (Soal No.1) }\end{array}$ & 264 & $70,4 \%$ & 334 & $89,1 \%$ \\
\hline 4 & $\begin{array}{l}\text { Disediakan ilustrasi tentang } \\
\text { kebun berbentuk persegi } \\
\text { panjang, siswa dapat } \\
\text { menentukan luas kebun } \\
\text { menggunakan rumus luas } \\
\text { persegi panjang dengan benar } \\
\text { (Soal No. 4) }\end{array}$ & 245 & $72,4 \%$ & 338 & $90,1 \%$ \\
\hline 5 & $\begin{array}{l}\text { Disediakan gambar } \\
\text { perbandingan dua lahan } \\
\text { berbentuk persegi dan persegi } \\
\text { panjang, siswa dapat } \\
\text { menentukan keliling lahan } \\
\text { berbentuk persegi panjang } \\
\text { dengan benar (Soal No. 2) }\end{array}$ & 474 & $63,2 \%$ & 517 & $68,9 \%$ \\
\hline
\end{tabular}

Berdasarkan data pada tabel di atas, diketahui hal sebagai berikut. Skor rata-rata kelas eksperimen adalah 80,72. Sedangkan skor rata-rata kelas kontrol adalah 64,24. Sehingga untuk kelas kontrol skornya di bawah KKM 70. 
Peneliti juga mengambil hasil kerja dari 2 siswa pada post-test masingmasing kelas kontrol dan kelas eksperimen. Penyelesaian soal esai memaparkan bagaimana siswa mengidentifikasi bagian yang diketahui, ditanyakan, dan menjawab dengan operasi hitung yang tepat (Kaprinaputri, 2013). Soal esai berupa soal cerita yaitu bentuk evaluasi terhadap kemampuan konsep matematika yang dimiliki siswa (Wahyuddin, 2016). Adapun jawaban siswa pada kelas eksperimen pada soal nomor 5 sebagai berikut.

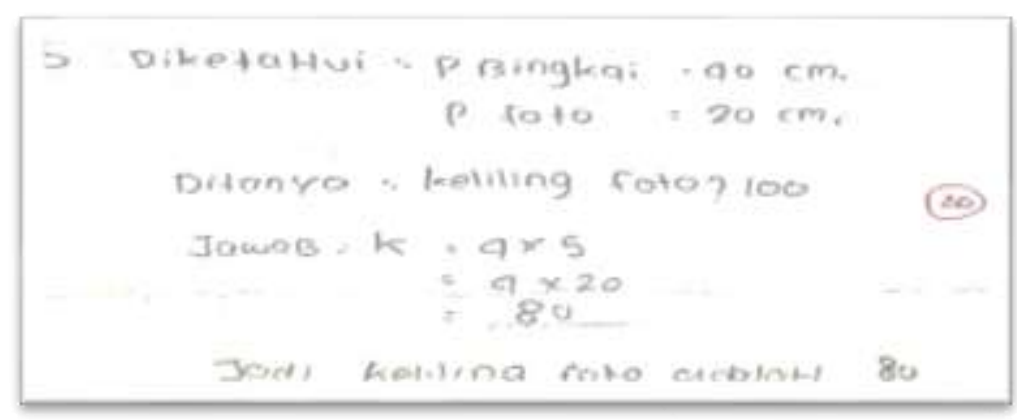

\section{Gambar 2. Jawaban Post-Test Nomor 5 pada Kelas Eksperimen}

Siswa kelas eksperimen menjawab lebih tepat daripada siswa kelas kontrol. Pada kelas eksperimen, rata-rata siswa dapat melakukan generalisasi konsep lebih banyak dari pada kelas kontrol. Siswa mampu menuliskan apa yang diketahui, apa yang ditanyakan dalam soal dan menjawab soal dengan menuliskan rumus persamaan matematika serta penyelesaiannya secara sistematis dan terstruktur. Hal ini menunjukkan bahwa siswa telah melewati fase belajar dengan baik (Syah, 2010: 120).

Siswa pada kelas kontrol dapat menentukan rumus matematika dan menghitung jawaban dari soal dengan benar, namun belum dapat menuliskan apa yang diketahui dan apa yang ditanyakan dari soal. Adapun jawaban siswa pada kelas kontrol adalah sebagai berikut.

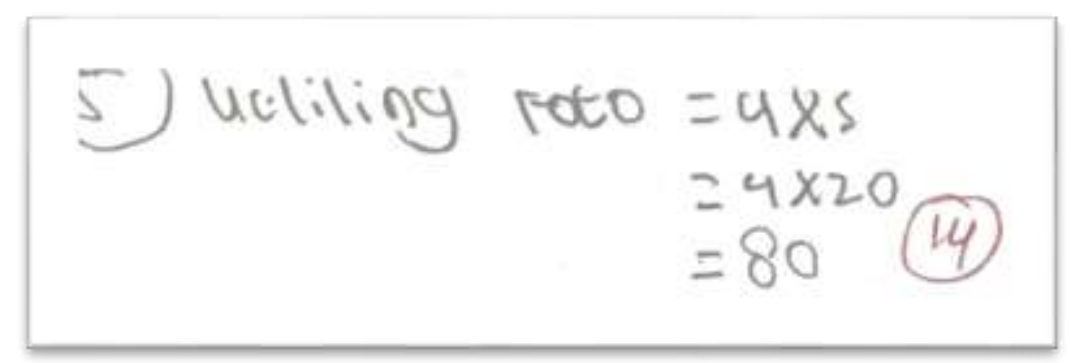

Gambar 3. Jawaban Post-Test Nomor 5 pada Kelas Kontrol 
Siswa menjawab soal nomor 5 tanpa menuliskan apa yang diketahui dan apa yang ditanyakan dalam soal. Hal ini menunjukkan bahwa siswa tidak melaksanakan fase belajar dengan baik (Syah, 2009). Siswa tidak menyelesaikan soal secara prosedural dan hanya menuliskan rumus matematika serta menjawab pada tahap penyelesaian soal.

Penelitian ini sesuai dengan penelitian Aini (2016) yang membuktikan bahwa model pembelajaran STAD berpengaruh positif terhadap hasil belajar. Model pembelajaran STAD ini tidak akan terlaksana dengan baik tanpa adanya kerjasama antar siswa dalam sebuah tim untuk memahami materi yang diajarkan dalam kegiatan pembelajaran serta kesesuaian bahan ajar dengan tujuan pembelajaran. Meninjau hal tersebut, maka sebuah kerjasama antar siswa dalam memahami suatu materi pembelajaran berperan penting dalam tercapainya orientasi pembelajaran yang fokus pada hasil belajar siswa. Hal tersebut selaras dengan (Hakiim, 2010) yang mengemukakan bahwa pembelajaran kooperatif mendorong siswa berinteraksi secara aktif dalam kelompok dengan mengacu pada tujuan pembelajaran bukan saja untuk diri sendiri, tetapi juga untuk teman dalam kelompok.

\section{KESIMPULAN DAN SARAN}

Berdasarkan deskripsi pada pembahasan, dapat disimpulkan bahwa ada perbedaan hasil belajar siswa yang menggunakan model pembelajaran Student Teams Achievement Division (STAD) dan pembelajaran konvensional pada materi keliling dan luas bangun datar. Nilai rata-rata kelas yang menggunakan pembelajaran konvensional hanya mengalami kenaikan sebesar 9,88\% dari 54,36 menjadi 64,24, sedangkan nilai rata-rata kelas yang menggunakan pembelajaran STAD mencapai $24,92 \%$ dari 55,80 menjadi 80,72 .

Adapun saran dari penelitian ini adalah kepada guru sekolah dasar untuk menerapkan model pembelajaran kooperatif STAD dalam kegiatan pembelajaran di kelas. Penelitian selanjutnya dapat menggunakan deskriptor pada penelitian ini sebagai dasar acuan penyusunan prosedur dalam penerapan model pembelajaran STAD serta penyusunan penelitian selanjutnya yang sejenis.

\section{DAFTAR RUJUKAN}

Aini, M. (2016). Pengaruh Penggunaan Model Pembelajaran Kooperatif Tipe Student Teams Achievement Divisions (STAD) Terhadap Hasil Belajar IPS Siswa Kelas V SD Negeri 1 Gunung Terang Kecamatan Tanjung Karang Barat Tahun Ajaran 2015/2016. Universitas Lampung. 
Depdiknas. (2007). Standar Isi. Jakarta: Permendikbud No. 21 Tahun 2006 tentang Standar Isi Pendidikan Dasar dan Menengah.

Dimyati, \& Mudjiono. (2006). Belajar dan Pembelajaran. Jakarta: Rineka Cipta.

Fuadi, R., Johar, R., \& Munzir, S. (2016). Peningkatan Kemampuan Pemahaman dan penalaran Matematis Melalui Pendekatan Kontekstual. Jurnal Didaktika, 3(1), 47-54.

Hadi, S. (2019). TIMSS Indonesia (Trends in International Mathematics and Science Study). In Prosiding Seminar Nasional \& Call for Papers. Tasikmalaya: Program Studi Magister Pendidikan Matematika Universitas Siliwangi.

Hakiim, L. (2010). Perencanaan Pembelajaran. Bandung: CV Wacana Prima.

Kaprinaputri, A. P. (2013). Kemampuan Menyelesaikan Soal Cerita Matematika. JIV, 8(1). https://doi.org/10.21009/jiv.0801.2

Mulyadi, M. (2011). Penelitian Kuantitatif dan Kualitatif Serta Pemikiran Dasar Menggabungkannya. Jurnal Studi Komunikasi Dan Media, 15(2), 127-138. https://doi.org/10.31445/jskm.2011.150106

National Council Of Teachers Of Mathematics. (2000). Principles and Standards for School Mathematics. School Science and Mathematics. https://doi.org/10.1111/j.1949-8594.2001.tb17957.x

Riadi, E. S. (2016). Studi Komparasi Penggunaan strategi Pembelajaran Kooperatif Tipe STAD dan Strategi Konvensional terhadap Hasil Belajar Matematika. Edumatica: Jurnal Pendidikan Matematika, 6(2).

Ruseffendi, E. T. (2005). Pengantar kepada Membantu Guru Mengembangkan Kompetensinya dalam Pengajaran Matematika untuk Meningkatkan CBSA. Bandung: Tarsito.

Suprijono, A. (2009). Cooperative Learning Teori dan Aplikasi PAIKEM. Yogyakarta: Pustaka Media.

Syah, M. (2009). Psikologi Belajar. Jakarta: PT Raja Grafindo Persada.

Wahyuddin. (2016). Analisis Kemampuan Menyelesaikan Soal Cerita Matematika Ditinjau dari Kemampuan Verbal. Beta Jurnal Tadris Matematika, 9(2), 148-160. https://doi.org/10.20414/betajtm.v9i2.9

Zalima, E. I., Njanji, F. P., Lasmiatik, L., Agustina, L., \& Dela, M. (2020). Analisis Kesulitan Siswa dalam Menyelesaikan Soal Cerita Operasi Hitung pada Bilangan Pecahan Campuran. Prismatika: Jurnal Pendidikan Dan Riset Matematika, 2(2). https://doi.org/10.33503/prismatika.v2i2.658 